\title{
Penggunaan Model Pembelajaran Course Review Horay Dengan Media Flipchart Sebagai Upaya Meningkatkan Hasil Belajar PKn
}

\author{
Nani Mediatati ${ }^{1}$, Istiana Suryaningsih ${ }^{2}$ \\ 1 Prodi PPKn Universitas Kristen Satya Wacana \\ ${ }^{2}$ Prodi PGSD Universitas Kristen Satya Wacana
}

\begin{abstract}
Abstrak
Model pembelajaran PKn dengan ceramah dan tidak digunakannya media menyebabkan siswa mudah bosan dan kurang aktif dalam pembelajaran. Berdasarkan hasil tes, hasil belajar PKn siswa kelas V SD Negeri Bugel 01 Salatiga yang tuntas mencapai KKM $\geq 70$ hanya $37,5 \%$ dan $62,5 \%$ belum tuntas. Penelitian Tindakan Kelas ini bertujuan untuk meningkatkan hasil belajar PKn melalui penggunaan model pembelajaran course review horay dengan media flipchart. Penelitian dilakukan dalam dua siklus dimana setiap siklus terdiri dari perencanaan, pelaksanaan, observasi, serta refleksi. Subjek penelitian adalah siswa kelas V yang berjumlah 16 orang. Instrumen pengumpulan data berupa lembar observasi dan soal tes pilihan ganda yang telah diuji validitas dan reliabilitasnya. Analisis data menggunakan deskriptif komparatif untuk data kuantitatif yaitu membandingkan ketuntasan hasil belajar PKn siswa pada kondisi awal, siklus I dan siklus II serta analisis kritis untuk data kualitatif dari hasil observasi. Hasil penelitian menunjukkan bahwa ketuntasan hasil belajar siswa dengan KKM $\geq 70$ setelah dilakukan tindakan pada siklus I meningkat menjadi $75 \%$ dan pada siklus II mencapai $100 \%$. Berdasarkan hasil penelitian ini dapat disimpulkan bahwa penggunaan model pembelajaran course review horay dengan media flipchart dapat meningkatkan hasil belajar PKn siswa kelas V SD Negeri Bugel 01 Salatiga Semester II Tahun Pelajaran $2015 / 2016$.
\end{abstract}

\begin{tabular}{l} 
Kata Kunci: \\
\hline model pembelajaran \\
course review horay, \\
media flipchart, hasil \\
belajar PKn
\end{tabular}

\section{Pendahuluan}

Dalam Permendiknas Nomor 22 Tahun 2006 disebutkan bahwa Pendidikan Kewarganegaraan merupakan mata pelajaran yang memfokuskan pada pembentukan warga negara yang memahami dan mampu melaksanakan hak-hak dan kewajibannya untuk menjadi warga negara Indonesia yang cerdas, terampil, dan berkarakter yang diamanatkan oleh Pancasila dan UUD 1945. Adapun tujuan Pendidikan Kewarganegaraan di SD adalah untuk membekali siswa berpikir kritis, rasional, kreatif dalam menanggapi isu kewarganegaraan; berpartisipasi secara aktif dan bertanggung jawab dalam kegiatan bermasyarakat, berbangsa dan bernegara serta anti korupsi; berkembang secara positif dan demokratis berdasarkan karakter masyarakat Indonesia agar dapat hidup bersama dengan bangsa lainnya; dan dapat berinteraksi dengan bangsa-bangsa lain secara langsung maupun tidak langsung dengan memanfaatkan teknologi dan informasi (Mawardi dan Suroso, 2009). Untuk mencapai tujuan tersebut maka diperlukan model pembelajaran yang lebih mengaktifkan siswa agar kemampuan berpikirnya dapat berkembang, dan dalam pembelajaran harus ada interaksi baik antara siswa dengan guru, maupun siswa dengan siswa lainnya agar siswa dapat berkembang menjadi pribadi yang demokratis dan bertanggung jawab serta dapat berinteraksi dengan orang lain dalam kehidupan bermasyarakat, berbangsa, dan bernegara. Hal ini sejalan dengan pendapat Utami (2010) yang menyatakan bahwa dalam pembelajaran PKn di SD guru harus memberi kesempatan yang luas pada siswa untuk membentuk pengetahuannya dengan berpikir kritis, sehingga guru tidak lagi menerapkan model pembelajaran konvensional yang monologis dan memaksa siswa menghafal konsep-konsep yang abstrak. Namun demikian pada umumnya dalam pembelajaran PKn guru belum menggunakan model pembelajaran yang melatih siswa untuk berpikir kritis dan menjadi pribadi yang demokratis dengan berinteraksi dengan guru dan siswa lainnya.

Hal ini juga terjadi di SD Negeri Bugel 01 Salatiga, berdasarkan hasil observasi dan wawancara

\footnotetext{
* Corresponding author.

E-mails: nanimediatati@yahoo.com (Nani Mediatati) suryaningsih@gmail.com (Istiana Suryaningsih)
} 
yang dilakukan dengan guru kelas kelas V ditemukan bahwa dalam pembelajaran PKn guru menggunakan model ceramah kemudian dilanjutkan pemberian tugas, akibatnya siswa menjadi kurang antusias dan aktif serta mudah bosan dalam pembelajaran sehingga pemahaman siswa terhadap materi yang disajikan menjadi berkurang. Guru juga belum menggunakan media pembelajaran sehingga siswa kurang tertarik pada materi yang disajikan. Akibatnya hasil belajar PKn sebagian besar siswa belum mencapai Kriteria Ketuntasan Minimal (KKM) yang ditentukan sekolah yaitu $\geq 70$. Dari 16 siswa ditemukan 10 siswa $(62,5 \%)$ belum mencapai KKM, hanya 6 siswa (37,5\%) yang mencapai KKM dengan nilai rata-rata kelas 68,25 yang juga belum mencapai KKM. Untuk mengatasi masalah tersebut, maka guru harus menciptakan suasana pembelajaran yang menyenangkan agar siswa tertarik pada materi pelajaran PKn, tidak mudah bosan, antusias dan aktif dalam pembelajaran PKn sehingga hasil belajar siswa meningkat. Guru harus mengembangkan pembelajaran yang sesuai dengan karakteristik anak usia Sekolah Dasar yaitu dengan menciptakan pembelajaran yang mengandung unsur permainan, bekerja atau belajar dalam kelompok dan memberikan kesempatan untuk terlibat langsung dalam pembelajaran (Desmita, 2014). Dengan model pembelajaran yang sesuai dengan karakteristik atau kondisi siswa serta bahan dan sumber belajar akan menunjang keberhasilan belajar siswa (Kurniasih dan Sani, 2015).

Salah satu model pembelajaran yang dapat digunakan untuk meningkatkan hasil belajar PKn dan sesuai dengan karakteristik anak usia SD adalah model pembelajaran course review horay. Menurut Kurniasih dan Sani (2015) model pembelajaran course review horay adalah model yang dapat menciptakan suasana kelas menjadi meriah dan menyenangkan karena setiap siswa yang dapat menjawab dengan benar maka siswa tersebut diwajibkan berteriak "hore" atau yel-yel yang disepakati. Selanjutnya Huda (2013) menjelaskan bahwa model pembelajaran course review horay membantu siswa untuk memahami konsep dengan baik melalui diskusi kelompok karena dengan model ini akan dilakukan pengujian pemahaman siswa pada materi pelajaran dan langsung dibahas sehingga siswa dapat langsung mengetahui jawabannya benar atau salah. Model ini melatih siswa menyelesaikan masalah, siswa yang paling terdahulu mendapatkan tanda benar berteriak hore atau yel-yel lainnya. Model pembelajaran course review horay juga memiliki kelebihan diantaranya menciptakan suasana pembelajaran yang menyenangkan karena diselingi dengan hiburan dan melatih kerja sama dalam menjawab soal yang diberikan oleh guru secara kelompok.

Saat siswa terbiasa menjawab soal dan dilakukan pembahasan secara langsung, siswa akan lebih memahami materi pembelajaran sehingga diharapkan hasil belajarnya meningkat. Adapun langkahlangkah model pembelajaran course review horay meliputi: (1) Guru menyampaikan kompetensi yang ingin dicapai, (2) Guru mendemostrasikan atau menyajikan materi, (3) Memberikan kesempatan siswa untuk tanya jawab, (4) Untuk menguji pemahaman siswa disuruh membuat kotak 9/ 16/ 25 sesuai dengan kebutuhan dan tiap kotak diisi angka sesuai dengan selera masing-masing siswa, (5) Guru membaca soal secara acak dan siswa menulis jawaban di dalam kotak yang nomornya disebutkan guru dan langsung didiskusikan, kalau benar diisi tanda benar $(\checkmark)$ dan salah diisi tanda silang (x), (6) Siswa yang telah mendapatkan tanda $(\checkmark)$ vertikal, horisontal atau diagonal harus berteriak hore... atau yel-yel lainnya, (7) Nilai siswa dihitung dari jawaban benar jumlah hore yang diperoleh, (8) Penutup (Suprijono,2013). Model pembelajaran course review horay ini dapat digunakan untuk berbagai mata pelajaran (PKn, Bahasa Indonesia, IPS, IPA, Matematika dll.

Model pembelajaran Course Review Horay merupakan model pembelajaran yang dapat menciptakan suasana kelas menjadi meriah dan menyenangkan karena setiap siswa yang dapat menjawab benar diwajibkan berteriak 'horee!!' atau yel-yel lainnya yang disukai (Miftahul Huda, 2013). Sedangkan menurut Imran (dalam Nur Malechah, 2011) model pembelajaran Course Review Horay merupakan suatu model pembelajaran dengan pengujian pemahaman menggunakan kotak yang diisi dengan nomor untuk menuliskan jawabannya, yang paling dulu mendapatkan tanda benar vertikal atau horisontal, atau diagonal langsung berteriak horey Selaras dengan pendapat tersebut, Dwitantra (2010) berpendapat bahwa model pembelajaran Course Review Horay adalah suatu metode pembelajaran dengan pengujian pemahaman menggunakan kotak yang diisi dengan nomor untuk menuliskan jawabannya, yang paling dulu mendapatkan tanda benar langsung berteriak horay. Model Course Review Horay berusaha menguji pemahaman siswa dalam menjawab soal.

Keunggulan dari model pembelajaran Course Review Horay: 1) Siswa ikutaktif dalam belajar. 2) Melatih kerjasama dan kemampuan siswa dalam menyelesaikan masalah. 3) Suasana belajar dan interaksi yang menyenangkanmembuat siswa lebih menikmati pelajaran sehingga siswa tidak mudah bosan untuk belajar. 4) Melatih siswa untuk mencapai tujuan-tujuan hubungan sosialyang pada akhirnya mempengaruhi prestasi akademik siswa. Kelemahan dari model pembelajaran Course Review Horay: 1) Siswa yang aktif dan pasif nilainya disamakan. Solusinya guru harus benar-benar mengontrol jalannya diskusi supaya siswa menjadi lebih aktif dalam diskusi. 2) Adanya peluang untuk curang. Solusinya pada lembar jawaban siswa tidak boleh ada coret-coret (armirifi, 2012). 
Kusumarini (2012) menyatakan bahwa, model pembelajaran course review horay merupakan salah satu pembelajaran kooperatif yaitu kegiatan belajar mengajar dengan cara mengelompokkan siswa ke dalam kelompok-kelompok kecil. Melalui pembelajaran course review horay diharapkan siswa dapat menyelesaikan masalah dengan pembentukan kelompok kecil.

Dalam aplikasinya metode pembelajaran Course Review Horay tidak hanya menginginkan siswa untuk belajar ketrampilan dan isi akademik. Course Review Horay sebagai salah satu proses learning to know, learning to do, learning to be and learning to live together untuk mendorong terciptanya kebermaknaan belajar bagi peserta didik (Suprijono, 2010). Melalui pembelajaran Course Review Horay diharapkan dapat melatih siswa dalam menyelesaikan masalah dengan pembentukan kelompok kecil (Natalia Ernawati: 2009). Adapun langkah-langkah yang harus ditempuh oleh guru dalam menggunakan model pembelajaran Course Review Horay adalah sebagai berikut: a) Guru menyampaikan kompetensi yang ingin dicapai, b) Guru menyajikan atau mendemons trasikan materi dengan Tanya jawab, c) Guru membagi siswa dalam kelompok-kelompok kecil 4-5 orang dalam satu kelompok, d) Untuk menguji pemahaman, siswa diminta membuat kartu atau kotak sesuai dengan kebutuhan dan diisi dengan nomor yang ditentukan guru, e) Guru membaca soal secara acak dan siswa menuliskan jawabannya didalam kartu atau kotak yang nomornya disebutkan guru, f) Setelah pembacaan soal dan jawaban siswa telah ditulis didalam kartu atau kotak, guru dan siswa mendiskusikan soal yang telah diberikan tadi, g) Bagi yang benar, siswa memberi bintang dan langsung berteriak horey atau menyanyikan yel yel, h) Nilai siswa dihitung dari jawaban yang benar dan yang banyak berteriak horey, i) Guru memberikan reward pada yang memperoleh nilai tinggi atau yang banyak memperoleh horay.

Model pembelajaran course review horay akan lebih berhasil apabila dilengkapi dengan media pembelajaran karena materi pembelajaran dapat lebih mudah dipahami dan siswa lebih tertarik pada pembelajaran. Hal ini sejalan dengan pendapat Briggs (Susilana dan Riyana,2009) yang menjelaskan bahwa media pembelajaran adalah alat untuk memberikan perangsang bagi siswa supaya terjadi proses belajar. Salah satu media yang dapat digunakan dalam pembelajaran PKn agar lebih menarik dan materi mudah dipahami siswa adalah media flipchart. Indriana (2011) menyatakan bahwa media flipchart adalah lembaran kertas berbentuk album atau kalender yang disusun dalam urutan, diikat pada bagian atasnya bisa diisi huruf, gambar, diagram, angka sehingga mampu menyajikan pesan pembelajaran secara ringkas. Penggunaan media flipchart dapat membuat materi pelajaran disampaikan dengan berbagai bentuk seperti penambahan gambar, huruf, diagram, bagan sehingga siswa tertarik dan tidak mudah bosan pada materi pelajaran yang disajikan, selain itu materi pelajaran disajikan secara ringkas sehingga akan mempermudah pemahaman siswa. Kustandi dan Sudjipto (2013) juga menjelaskan bahwa media flipchart adalah lembaran kertas dengan ukuran sama yang berisikan bahan pelajaran yang disusun rapi untuk menghemat waktu menulis di papan tulis yang berupa gambar-gambar, diagram, huruf-huruf atau angka-angka. Kelebihan dari media lembar balik atau flipchart yaitu bermanfaat untuk menyajikan bahan pelajaran secara bertahap, gambar yang digunakan dapat disimpan dengan baik sehingga dapat digunakan berulang-ulang, waktu tidak banyak terbuang dalam menyajikan materi karena pengajar telah menyiapkan materi sebelumnya, lebih menarik perhatian dan minat siswa (Sanaky,2013).

Dengan demikian melalui penggunaan model pembelajaran course review horay dengan media flipchart dalam pembelajaran PPKn akan dapat meningkatkan hasil belajar siswa karena suasana kelas meriah dan menyenangkan sehingga siswa antusias dan aktif dalam pembelajaran serta mudah memahami materi karena materi disajikan secara ringkas melalui media yang menarik. Hasil belajar menurut Fathurrohman dan Wuryandari (2013) adalah kemampuan yang dimiliki peserta didik setelah mengalami aktivitas belajar, begitu juga dengan Purwanto (2014) menyatakan bahwa hasil belajar merupakan kemampuan yang dimiliki oleh siswa setelah menerima pengalaman belajar. Dalam proses pembelajaran untuk mengetahui sejauh mana siswa menguasai bahan yang sudah diajarkan oleh guru, maka dilakukan tes hasil belajar. Dengan demikian dapat dikatakan bahwa hasil belajar adalah tingkat penguasaan materi yang dicapai siswa setelah mengikuti proses pembelajaran.

Ada beberapa penelitian yang menunjukkan bahwa penggunaan model pembelajaran course review horay dan media flipchart dapat meningkatkan hasil belajar siswa diantaranya adalah penelitian Siska Fitriani (2013) yang menunjukkan adanya peningkatan hasil belajar matematika siswa kelas 3 SD N Winong 01 Kecamatan Pati Kabupaten Pati Semester 1 Tahun Pelajaran 2013/2014 setelah diterapkan model pembelajaran course review horay. Selanjutnya penelitian Vita Nur Fatimah (2013) yang menunjukkan bahwa dengan penggunaan model pembelajaran course review horay dapat meningkatkan keaktifan dan hasil belajar siswa pada mata pelajaran Bahasa Indonesia di Kelas V SD N Pledokan Kecamatan Sumowono Kabupaten Semarang Tahun Ajaran 2012/2013. Kemudian penelitian Desi Eka Pratiwi (2013) yang menunjukkan bahwa penerapan media papan balik (flipchart) pada pembelajaran tematik materi pelajaran bahasa Indonesia dan matematika dapat meningkatkan hasil belajar siswa kelas 
II SD N Senambung No 296 Sidorejo. Berdasarkan ketiga hasil penelitian tersebut menunjukkan bahwa penggunaan model pembelajaran course review horay dan media flipchart dapat meningkatkan hasil belajar siswa SD dalam mata pelajaran matematika dan bahasa Indonesia. Mengacu pada kajian teori dan hasil penelitian sebelumnya maka dilakukan penelitian tindakan kelas untuk meningkatkan hasil belajar PKn siswa kelas V SD Negeri Bugel 01 Salatiga Semester II Tahun 2015/2016 dengan menggunakan model pembelajaran couse review horay dan media flipchart.

\section{Metode}

Penelitian yang dilaksanakan adalah Penelitian Tindakan Kelas dengan menggunakan desain penelitian Kemmis Mc Taggart yang terdiri dari empat komponen yaitu perencanan (planning), pelaksanan tindakan (acting), pengamatan (observation), serta refleksi (reflection) yang dipandang sebagai satu siklus (Tampubolon, 2014).

Penelitian ini dilakukan di kelas V SD Negeri Bugel 01 Kelurahan Bugel, Kecamatan Sidorejo, Kota Salatiga pada semester II tahun pelajaran 2015/2016. Subjek penelitian adalah siswa kelas V yang berjumlah 16 orang. Penelitian ini direncanakan dalam dua siklus, dengan rincian kegiatan sebagai berikut: 1) Siklus I, terdiri dari tahap: a) Perencanaan, pada tahap ini peneliti mempersiapkan RPP disesuaikan dengan model pembelajaran course review horay untuk dua kali pertemuan, setiap pertemuan 2 x 35 menit, mempersiapkan media flipchart, mempersiapkan soal evaluasi, membuat lembar observasi aktivitas guru dan siswa dalam kegiatan pembelajaran; b) Pelaksanaan dan pengamatan, pada tahap ini dilakukan pelaksanaan RPP yang telah dibuat. Pada akhir siklus I siswa diberikan soal evaluasi untuk mengetahui hasil belajar siswa setelah pelaksanaan tindakan. Bersamaan dengan itu peneliti melakukan pengamatan sesuai dengan lembar observasi kegiatan pembelajaran menggunakan model pembelajaran course review horay dan media flipchart yang telah dipersiapkan sebelumnya; c) Tahap refleksi, tahap ini dilakukan setiap akhir proses pembelajaran untuk mengetahui kelebihan dan kekurangan/hambatan dalam pelaksanaan model pembelajaran course review horay dengan media flipchart. Selain itu juga dibandingkan hasil belajar PKn setelah pelaksanaan model pembelajaran course review horay dengan media flipchart pada siklus I dan sebelum tindakan. 2) Siklus II, Siklus II dirancang berdasarkan hasil refleksi yang telah dilakukan pada siklus I, hambatan dan kekurangan yang terjadi di siklus I dicari pemecahannya agar tidak terulang di siklus II sedangkan kelebihan yang ada ditingkatkan lagi di siklus II. Siklus II juga dilakukan dengan tahap-tahap yang sama dari siklus I yaitu perencanaan, pelaksanaan dan observasi serta refleksi.

Teknik pengumpulan data menggunakan: (1) dokumentasi untuk rekap nilai ulangan harian siswa sebelum dilakukan penelitian dan untuk mencari data siswa, (2) observasi untuk mengamati dan mencatat aktivitas guru dan siswa dalam proses pembelajaran PKn menggunakan model pembelajaran course review horay dengan media flipchart menggunakan pedoman/lembar observasi, dan (3) tes obyektif bentuk pilihan ganda untuk mengetahui hasil belajar siswa setelah penerapan model pembelajaran course review horay dengan media flipchart yang diberikan pada setiap akhir siklus. Instrumen pengumpulan data dalam penelitian ini berupa lembar observasi dan soal tes bentuk pilihan ganda yang telah diuji validitas dan reliabilitasnya.

Teknik analisis data menggunakan teknik deskriptif komparatif untuk analisis data kuantitatif dengan membandingkan hasil belajar siswa sebelum tindakan, setelah tindakan siklus I dan siklus II serta teknik analisis kritis untuk analisis data kualitatif untuk mendeskripsikan kelemahan dan kelebihan aktivitas siswa dan guru dalam proses pembelajaran berdasarkan hasil pengamatan dan refleksi. Penelitian ini dikatakan berhasil jika penggunaan model pembelajaran course review horay dengan media flipchart dapat meningkatkan hasil belajar PKn siswa kelas V SD Negeri Bugel 01 yaitu 100\% siswa tuntas mencapai $\mathrm{KKM} \geq 70$.

\section{Hasil dan Pembahasan}

Siklus I dilakukan dua kali pertemuan. Pada tahap perencanaan peneliti menyusun RPP berdasarkan langkah-langkah model pembelajaran course review horay dengan KD 4.1 mengenal bentukbentuk keputusan bersama, selain itu juga dipersiapkan media flipchart dan lembar observasi untuk mencatat aktivitas guru dan siswa dalam pembelajaran PKn menggunakan model course review horay dengan media flipchart. Pelaksanaan pembelajaran dilakukan pada hari Senin, 28 Maret 2016 dan Rabu, 30 Maret 2016 sesuai dengan langkah-langkah pembelajaran menggunakan model pembelajaran course review horay dengan media flipchart dalam RPP. Pelaksanaan langkah-langkah model pembelajaran course review horay disesuaikan dengan tahapan dalam standar proses yang menjadi acuan dalam proses pembelajaran. Dalam pelaksanaan kegiatan pembelajaran terdapat tiga kegiatan sesuai dengan standar 
proses. Pertama: kegiatan pendahuluan, pada kegiatan ini guru mengucapkan salam, memeriksa kehadiran dan kesiapan siswa, memberi motivasi belajar, menyampaikan apersepsi, dan menyampaikan kompetensi dan tujuan pembelajaran yang ingin dicapai. Kedua: kegiatan inti yang dibagi dalam tahap eksplorasi, elaborasi, dan konfirmasi. Pada tahap eksplorasi, guru menjelaskan materi pembelajaran PKn dengan menggunakan media flipchart, lalu guru melakukan tanya jawab dengan siswa saat dan setelah menyampaikan materi pembelajaran dengan media flipchart.

Tahap elaborasi, guru membagi siswa dalam kelompok-kelompok kecil yang terdiri dari 3-4 orang, setiap kelompok diminta membuat kotak 9 untuk menuliskan jawaban pertanyaan yang diberikan guru secara kelompok, setiap kelompok diminta memberi nomor 1-9 pada kotak dan boleh menempatkan nomor tersebut secara acak sesuai selera siswa, selanjutnya guru membacakan pertanyaan secara acak, siswa diberi waktu untuk berdiskusi menjawab pertanyaan yang diberikan guru dan menuliskannya pada kotak. Setelah semua pertanyaan dibacakan dan jawaban dituliskan pada kotak, jawaban setiap kelompok didiskusikan atau dibahas bersama, kelompok yang menjawab pertanyaan dengan benar memberi tanda checklist $(\checkmark)$ pada kotak dan kelompok yang salah memberi tanda silang (x) pada kotak. Kelompok meneriakkan hore atau yel-yel yang telah disepakati jika mendapatkan tanda checklist ( $\checkmark$ ) horisontal, diagonal, atau vertikal. Kelompok yang memberikan jawaban yang benar dan berteriak hore mendapatkan poin, setiap kelompok diminta menghitung poin yang mereka dapatkan. Pada tahap konfirmasi, setiap kelompok diminta membacakan nilai yang didapatkan kemudian guru memberikan reward pada kelompok yang memperoleh nilai tertinggi, guru melakukan evaluasi model pembelajaran course review horay yang telah dilakukan, siswa diberikan kesempatan untuk bertanya hal-hal yang belum dipahami tentang materi yang telah disampaikan, dan terakhir guru memberikan penguatan pada siswa. Ketiga: kegiatan penutup, pada tahap ini siswa bersama guru menyimpulkan materi pelajaran atau membuat rangkuman lalu guru memberikan tindak lanjut berupa tugas, menyampaikan rencana pembelajaran pada pertemuan berikutnya dan mengucapkan salam penutup. Pada akhir siklus yaitu pertemuan kedua siswa diberikan soal evaluasi untuk mengetahui hasil belajar siswa.

Hasil refleksi setelah proses pembelajaran, ditemukan guru telah melakukan langkah-langkah pembelajaran menggunakan model pembelajaran course review horay dengan media flipchart dengan baik, namun masih terdapat kekurangan dalam pembelajaran yaitu pada saat penjelasan pokok-pokok materi dengan menggunakan media flipchart masih ada siswa yang kurang memperhatikan, dalam kegiatan diskusi ada kelompok yang kurang berkonsentrasi mendengarkan pertanyaan yang dibacakan guru sehingga diperlukan tambahan waktu untuk melanjutkan ke pertanyaan berikutnya untuk menunggu kelompok tersebut, akibatnya kegiatan pembelajaran melebihi 10 menit dari waktu yang dialokasikan. Selain itu masih ada beberapa siswa yang belum aktif bekerjasama untuk menjawab dan menuliskan jawaban dari soal yang dibacakan guru secara acak. Untuk mengatasi kekurangan tersebut maka perbaikan yang akan dilakukan pada siklus II adalah guru melibatkan siswa dalam penyampaian materi dengan menggunakan media flipchart misalnya dengan menunjuk siswa untuk maju ke depan membaca materi sehingga semua siswa akan lebih aktif dan memperhatikan penyampaian materi. Dalam kegiatan diskusi guru harus lebih mengkondisikan siswa untuk berkonsentrasi dalam mendengar dan menjawab pertanyaan, selain itu agar waktu tidak habis untuk kegiatan diskusi harus ada peraturan yang jelas, jika diperlukan perlu ada pembatasan waktu dalam menjawab pertanyaan. Guru mengingatkan dan memantau siswa dalam diskusi kelompok agar selalu bekerja sama, menegur siswa yang tidak mau berdiskusi atau memberikan aturan jika siswa belum berdiskusi dengan baik poinnya akan dikurangi.

Hasil evaluasi menunjukkan bahwa hasil belajar PKn siswa kelas V SD Negeri Bugel 01 Salatiga pada siklus I sudah mengalami peningkatan dibandingkan kondisi awal, hal ini dapat dilihat banyaknya siswa yang tuntas jumlahnya meningkat menjadi 12 orang (75\%) dengan nilai rata-rata juga mengalami peningkatan yaitu 75,31 dengan nilai tertinggi: 95 dan nilai terendah: 60. Pada kondisi awal siswa yang tuntas hanya 6 orang $(37,5 \%)$ dengan nilai rata-rata 68,25, nilai tertinggi: 88 dan nilai terendah: 52 . Hal tersebut dapat dilihat dalam tabel berikut ini.

Tabel 1. Perbandingan Hasil Belajar PKn Siswa Kelas V SD Negeri Bugel 01 Pada Kondisi Awal dan Siklus I

\begin{tabular}{lccccc}
\hline \multirow{2}{*}{ No $\quad$ Ketuntasan Belajar } & \multirow{2}{*}{ Nilai } & \multicolumn{2}{c}{ Kondisi awal } & \multicolumn{2}{c}{ Siklus I } \\
\cline { 3 - 6 } & & $\mathrm{F}$ & $\%$ & $\mathrm{~F}$ & $\%$ \\
\hline 1. Tuntas & $\geq 70$ & 6 & 37,5 & 12 & 75 \\
2. Belum tuntas & $<70$ & 10 & 62,5 & 4 & 25 \\
Jumlah & & 16 & 100 & 16 & 100 \\
Nilai Tertinggi & 88 & & 95 & \\
Nilai Terendah & 52 & 60 & 75,31 \\
\hline Nilai Rata-rata & \multicolumn{5}{c}{68,25} \\
\hline
\end{tabular}


Siklus II dilakukan dua kali pertemuan. Pada tahap perencanaan peneliti menyusun RPP dengan KD 4.2 mematuhi keputusan bersama berdasarkan hasil refleksi yang dilakukan pada siklus I, selain itu juga dipersiapkan media flipchart dan lembar observasi untuk mencatat aktivitas guru dan siswa dalam pembelajaran PKn menggunakan model course review horay dengan media flipchart. Pelaksanaan pembelajaran dilakukan pada hari Senin, 4 April 2016 dan Rabu, 6 April 2016 sesuai dengan langkahlangkah pembelajaran menggunakan model pembelajaran course review horay dengan media flipchart dalam RPP yang sama dengan siklus I namun dengan perbaikan sesuai hasil refleksi. Pada akhir pertemuan kedua siswa diberikan soal evaluasi untuk mengetahui hasil belajar siswa.

Hasil refleksi menunjukkan guru dan siswa telah melaksanakan semua langkah model pembelajaran course review horay dengan lebih baik jika dibandingkan siklus I, hal ini menyebabkan suasana pembelajaran menjadi lebih menyenangkan. Siswa semakin baik dalam bekerjasama dan melakukan diskusi dalam kelompoknya. Siswa juga semakin aktif dalam kegiatan tanya jawab yang dilakukan. Keterlibatan siswa secara langsung dalam penggunaan media flipchart membuat siswa lebih berkonsentrasi dan memperhatikan penjelasan yang diberikan oleh guru. Siswa juga dapat dikondisikan dalam meneriakkan yel-yelnya. Hasil evaluasi menunjukkan bahwa hasil belajar PKn siswa kelas V SD Negeri Bugel 01 Salatiga pada siklus II mengalami peningkatan dibandingkan hasil belajar siklus I. Semua siswa kelas V (100\%) telah tuntas mencapai KKM $\geq 70$ dengan nilai rata-rata 81,56, nilai tertinggi: 95 dan nilai terendah: 70. Hal tersebut dapat dilihat dalam tabel berikut ini.

Tabel.2 Perbandingan Hasil Belajar PKn Siswa Kelas V SD Negeri Bugel 01 Pada Siklus I dan Siklus II

\begin{tabular}{lccccc}
\hline No & Ketuntasan Belajar & \multirow{2}{*}{ Nilai } & Siklus I & \multicolumn{3}{c}{ Siklus II } \\
\cline { 3 - 6 } & & $\mathrm{F}$ & $\%$ & $\mathrm{~F}$ & $\%$ \\
\hline 1. $\quad$ Tuntas & $\geq 70$ & 12 & 75 & 16 & 100 \\
2. Belum tuntas & $<70$ & 4 & 25 & 0 & 0 \\
Jumlah & & 16 & 100 & 16 & 100 \\
Nilai Tertinggi & 95 & & 95 & \\
Nilai Terendah & 60 & 70 \\
\hline Nilai & & 75,31 & \multicolumn{3}{c}{81,56} \\
\hline
\end{tabular}

Peningkatan hasil belajar PKn siswa kelas V setelah dilakukan tindakan pembelajaran menggunakan model course review horay dengan media flipchart pada siklus I dan siklus II dibandingkan dengan kondisi awal sebelum dilakukan tindakan dapat dilihat pada tabel berikut ini.

Tabel 3. Perbandingan Hasil Belajar PKn Siswa Kelas V SD Negeri Bugel 01 Pada Kondisi Awal, Siklus I dan Siklus II

\begin{tabular}{lccccccc}
\hline \multirow{2}{*}{ No Ketuntasan Belajar } & \multirow{2}{*}{ Nilai } & \multicolumn{2}{c}{ Kondisi awal } & \multicolumn{2}{c}{ Siklus I } & \multicolumn{2}{c}{ Siklus II } \\
\cline { 3 - 8 } & & $\mathrm{F}$ & $\%$ & $\mathrm{~F}$ & $\%$ & $\mathrm{~F}$ & $\%$ \\
\hline 1. Tuntas & $\geq 70$ & 6 & 37,5 & 12 & 75 & 16 & 100 \\
2. Belum tuntas & $<70$ & 10 & 62,5 & 4 & 25 & 0 & 0 \\
Jumlah & & 16 & 100 & 16 & 100 & 16 & 100 \\
Nilai Tertinggi & 88 & & 95 & & 95 & \\
Nilai Terendah & 52 & 60 & \multicolumn{3}{c}{81,56} \\
\hline Nilai Rata-rata & \multicolumn{2}{c}{68,25} & \multicolumn{7}{c}{75,31} \\
\hline
\end{tabular}

Berdasarkan data dalam tabel di atas, dapat dilihat terjadi peningkatan ketuntasan hasil belajar siswa dari kondisi awal, ke siklus I dan siklus II. Dari 6 siswa atau 37,5 \% dari keseluruhan siswa yang tuntas pada kondisi awal meningkat menjadi 12 siswa atau 75\% dari keseluruhan siswa yang tuntas dan pada siklus II meningkat lagi menjadi 16 siswa atau 100\% siswa sudah tuntas. Selain itu nilai rata-rata juga mengalami peningkatan yaitu pada kondisi awal 68,25, siklus I menjadi 75, 31, dan siklus II semakin meningkat menjadi 81,56. Berdasarkan hasil tersebut maka dapat disimpulkan bahwa penggunaan model pembelajaran course review horay dengan media flipchart dalam pembelajaran PKn terbukti dapat meningkatkan hasil belajar siswa sesuai dengan indikator keberhasilan penelitian yaitu $100 \%$ siswa mencapai ketuntasan belajar dengan KKM $\geq 70$.

Dalam pembelajaran PKn guru cenderung menggunakan metode ceramah dalam penyampaian materi dan tidak menggunakan media pembelajaran. Hal ini menyebabkan siswa kurang tertarik pada pembelajaran PKn, siswa mudah bosan, kurang aktif, dan kurang bersemangat mengikuti pembelajaran. 
Oleh karena itu sebagian besar siswa tidak mencapai ketuntasan belajar dengan KKM $\geq 70$. Dari 16 siswa kelas V SD Negeri Bugel 01 Salatiga yang mencapai ketuntasan belajar hanya ada 6 siswa (37,5\%) dan 10 siswa $(62,5 \%)$ tidak tuntas dengan nilai rata-rata 68,25. Setelah dilakukan tindakan perbaikan pembelajaran menggunakan model pembelajaran course review horay dengan media flipchart sebagai upaya untuk meningkatkan hasil belajar PKn siswa kelas V, siswa menjadi aktif, antusias dan bersemangat dalam pembelajaran, mudah memahami materi karena dibantu media dan juga diskusi/kerjasama dengan teman, sehingga hasil belajarnya meningkat. Pada siklus I hasil belajar siswa meningkat, siswa yang tuntas belajarnya ada 12 siswa (75\%) dan siswa yang tidak tuntas ada 4 siswa (25\%) dengan nilai rata-rata kelas 75,31. Jika dibandingkan dengan kondisi awal, hasil belajar siswa telah mengalami peningkatan namun hasil ini belum mencapai indikator keberhasilan yang telah ditetapkan yaitu $100 \%$ siswa tuntas, selain itu dalam pelaksanaan pembelajaran masih terdapat kekurangan baik dari aktivitas guru maupun siswa. Oleh karena itu dilakukan tindakan perbaikan dengan pelaksanaan siklus II. Pada siklus II hasil belajar siswa semakin meningkat yaitu 16 siswa atau 100\% siswa telah mencapai ketuntasan dengan nilai rata-rata 81,56. Berdasarkan data tersebut dapat disimpulkan bahwa penggunaan model pembelajaran course review horay dengan media flipchart dapat meningkatkan hasil belajar PKn siswa kelas V SD Negeri Bugel 01 Salatiga.

Penerapan model pembelajaran course review horay membuat pembelajaran lebih menyenangkan karena pembelajaran yang dilakukan diselingi dengan yel-yel jika siswa mendapatkan tanda benar $(\checkmark)$ vertikal, horisontal, atau diagonal dan kelompok yang mendapatkan nilai tertinggi diberikan reward, selain itu siswa menjadi lebih tertarik dan bersemangat pada pembelajaran PKn. Siswa juga semakin aktif dalam pembelajaran yang dapat dilihat dari kegiatan tanya jawab dan diskusi dengan bekerjasama antar anggota kelompok untuk menjawab soal. Hal ini sesuai dengan pendapat Kurniasih dan Sani (2015) yang memaparkan kelebihan model pembelajaran course review horay yaitu menarik sehingga mendorong siswa terlibat di dalamnya, tidak monoton karena diselingi sedikit hiburan, siswa lebih bersemangat belajar sehingga tercipta suasana yang menyenangkan dan melatih kerja sama antar siswa di dalam kelas.

Penggunaan model course review horay memberikan dampak yang positif dalam pembelajaran yang dapat dilihat dari proses pembelajaran yang tidak lagi berpusat pada guru melainkan lebih melibatkan siswa, siswa lebih aktif dan antusias pada kegiatan tanya jawab dan diskusi untuk menyelesaikan soal yang dibacakan guru. Siswa menjawab soal yang dibacakan guru secara kelompok sehingga siswa yang kemampuannya dalam memahami dan menjawab soal kurang, dapat dibantu oleh teman satu kelompoknya, selain itu dengan dilakukannya pembahasan secara langsung siswa dapat mengetahui jawabannya itu benar atau salah sehingga siswa lebih memahami konsep/materi pelajaran. Model pembelajaran course review horay juga melatih siswa untuk berpikir kritis yaitu menilai dan memberikan alasan jawaban yang dituliskan merupakan jawaban yang benar atau jawaban yang salah. Melalui proses pembelajaran yang mengaktifkan dan memberikan semangat pada siswa, maka pemahaman konsep materi pelajaran menjadi lebih baik sehingga siswa dapat mencapai hasil belajar yang optimal. Hal ini sejalan dengan pendapat Huda (2013) yang memaparkan bahwa model pembelajaran course review horay dapat membantu siswa untuk memahami konsep dengan baik melalui diskusi kelompok. Selain itu dengan penggunaan media flipchart materi pelajaran disajikan secara lebih ringkas sehingga guru lebih mudah menyampaikan materi pembelajaran dan lebih menarik sehingga siswa lebih mudah memahami materi pelajaran. Media flipchart juga dapat menghemat waktu untuk menulis di papan tulis. Hal ini sesuai dengan pendapat yang disampaikan Susilana dan Riyana (2009) yang memaparkan kelebihan media flipchrt diantaranya mampu menyajikan pesan pembelajaran secara singkat dan praktis yang mencakup pokok-pokok materi pembelajaran. Juga pendapat yang dikemukakan Kustandi dan Sudjipto (2013) yang menyatakan bahwa penggunaan media flipchart merupakan salah satu cara guru dalam menghemat waktu menulis di papan tulis.

Hasil penelitian ini melengkapi dan memperkuat hasil penelitian terdahulu yang dilakukan oleh Siska Fitriani (2013) yang menunjukkan penerapan model pembelajaran course review horay dapat meningkatkan hasil belajar matematika siswa kelas 3 SD N Winong 01 Kecamatan Pati Kabupaten Pati Semester 1 Tahun Pelajaran 2013/2014. Selain itu penelitian Vita Nur Fatimah (2013) yang menunjukkan bahwa penggunaan model pembelajaran course review horay dapat meningkatkan hasil belajar siswa pada mata pelajaran Bahasa Indonesia Kelas V SD N Pledokan Kecamatan Sumowono Kabupaten Semarang tahun ajaran 2012/2013. Selanjutnya penelitian dari Desi Eka Pratiwi (2013) yang menunjukkan penggunaan media papan balik (flipchart) pada pembelajaran tematik materi pelajaran bahasa Indonesia dan matematika dapat meningkatkan hasil belajar siswa kelas II SD Negeri Semambung No. 296 Sidoarjo. 


\section{Simpulan dan Saran}

Berdasarkan hasil penelitian dan pembahasan dapat disimpulkan bahwa penggunaan model pembelajaran course review horay dengan media flipchart dapat meningkatkan hasil belajar PKn siswa kelas V semester II tahun pelajaran 2015/2016 SD Negeri Bugel 01 Salatiga. Pada kondisi awal hanya ada 6 siswa $(37,5 \%)$ yang tuntas dan 10 siswa $(62,5 \%)$ belum tuntas mencapai KKM $\geq 70$ dengan nilai ratarata 68,25. Setelah dilakukan tindakan pada silkus I hasil belajar siswa meningkat ada 12 siswa (75\%) tuntas dan 4 siswa (25\%) tidak tuntas dengan nilai rata-rata 75,31 dan pada siklus II hasil belajar siswa semakin meningkat yaitu 16 siswa (100\%) tuntas dengan nilai rata-rata 81,56.

Bagi guru, dapat menerapkan model pembelajaran course review horay dengan media flipchart dalam pembelajaran PKn karena terbukti dapat menciptakan suasana pembelajaran yang menyenangkan dan meningkatkan hasil belajar siswa. Bagi sekolah, penggunaan model pembelajaran course review horay dengan media flipchart dapat dijadikan referensi untuk meningkatkan kualitas proses dan hasil belajar siswa.

\section{Daftar Pustaka}

Agus Suarimbawa, Kadek., AAIN Marhaeni, GAP Suprianti. (2017). An Analysis of Authentic Assessment Implementation Based on Curriculum 2013 in SMP Negeri 4 Singaraja. Journal of Education Research and Evaluation. Vol. 1 No.1.

Agus, Suprijono. (2010). Cooperative Learning. Yogyakarta : Pustaka Pelajar.

Armirifi, (2012). Course Review Horay. (Online). (http//armirifi.blogspot. com./2012/12/course-reviewhoray.html, diakses 28 februari 2013).

Badan Standar Nasional Pendidikan. (2006). Lampiran Peranturan Menteri Pendidikan Nasional Nomor Nomor 22 Tahun 2006 Tentang Standar Isi. Tersedia di file http://bsnp-indonesia.org/id/wpcontent/uploads/isi/Standar_Isi.pdf. [diunduh pada tanggal 30 Januari 2016]

Desmita. (2014). Psikologi Perkembangan Peserta Didik. Bandung: Remaja Rosdakarya

Dwitantra.(2010). Model Pembelajaran Course Review Horay (CRH). [Online]. Tersedia: http://cheliemarlangen.blogspot.com/[27 Februari 2013].

Ernawati, dkk. (2009). Tata BusanaJilid 1 untuk Sekolah Menengah Kejuruan. Jakarta: Direktorat Pembinaan Sekolah Menengah Kejuruan.

Fathurrohman dan Wuri Wuryandari. (2011). Pembelajaran PKn di Sekolah Dasar untuk PGSD dan Guru $S D$. Yogyakarta: Nuha Litera

Fatimah, Vita Nur. (2013). Upaya Meningkatkan Keaktifan dan Hasil Belajar Menggunakan Model Course Review Horay (CRH) Pada Mata Pelajaran Bahasa Indonesia Kelas V SD N Pledokan Kecamatan Sumowono Kabupaten Semarang Tahun Ajaran 2012/2013. Skripsi UKSW. Tersedia di http://repository.uksw.edu/handle/123456789/4488. [diunduh pada tanggal 30 Januari 2016]

Fitriani, Siska. (2013). Penerapan Model Pembelajaran Course Review Horay Untuk Meningkatkan Hasil Belajar Matematika Siswa Kelas 3 SD N Winong 01 Kecamatan Pati Kabupaten Pati Semester 1 Tahun Pelajaran 2013/2014. Skripsi UKSW. Tersedia di http://repository.uksw.edu/handle/123456789/5278. [diunduh pada tanggal 30 Januari 2016]

Huda, Miftahul. (2013). Model-model Pengajaran dan Pembelajaran: Isu-isu Metodis dan Paradigmatis. Yogyakarta: Pustaka Belajar

Indriana, Dina. (2011). Ragam Alat Bantu Media Pengajaran. Yogyakarta: Diva Press

Kurniasih, Imas dan Berlin Sani. (2015). Ragam Pengembangan Model Pembelajaran Untuk Meningkatkan Profesionalisme Guru. Jakarta: Kata Pena

Kustandi, Cecep dan Bambang Sudjipto. (2013). Media Pembelajaran; Manual dan Digital Edisi Kedua. Bogor: Ghalia Indonesia

Kusumarini, Endah. (2012). Model Pembelajaran Course Review Horay. Tersedia pada http://rinkuchiki.blogspot.com/2012/06/model-pembelajaran-course-review-horay. html(diakses pada tanggal 17 Desember 2012). 
Mawardi dan Suroso. (2009). Pengembangan Pendidikan SD. Salatiga: Widya Sari Press

McCarthy, C. (2014). Multicultural discourses and curriculum reform: A critical perspective. Educational Theory, number 44-vol.1, page 81-83.

Nur, Malechah. (2011). Perbandingan Hasil Belajar Siswa dengan Menggunakan Model Pembelajaran Course Review Horey (CRH) dan Model Pembelajaran Scramble Berbantuan LKS pada Siswa Kelas VII Semester II SMPN 2 Sayung Demak Tahun Pelajaran 2010/2011. Diperoleh pada Agustus 2014. http://andynuriman.files.wordpress.com/2011/10/nur-malechah.p.

Nurliawaty, Lilis., Mujasam., Irfan Yusuf \& Sri Wahyu Widyaningsih. (2017). Lembar kerja peserta didik (LKPD) Berbasis problem solving polya. Jurnal Pendidikan Indonesia. Vol. 6, No.1, pp: 72-81

O’Sulivan, 1994) T. (Ed). (2014). Key Concept in Communication Cultural Studies. New York: Routledge, Pub.

Parwati, NN. (2015). Pengembangan Model Pembelajaran Pemecahan Masalah Berorientasi Kearifan Lokal Pada Siswa SMP di Kota Singaraja. Jurnal Pendidikan Indonesia. Vol. 4 No. 2.

Pratiwi, Desi Eka. (2013). Penerapan Media Papan Balik (Flipchart) Untuk Meningkatkan Hasil Belajar Siswa Sekolah Dasar. Jurnal Skripsi Universitas Negeri Surabaya. Tersedia di file Https://Id.Scribd.Com/Doc/189289720/Penerapan-Media-Papan-Balik-Flipchart-Pada-

Pembelajaran-Tematik-Untuk-Meningkatkan-Hasil-Belajar-Siswa-Sekolah-Dasar [diunduh pada tanggal 09 Februari2016]

Purwanto. (2014). Evaluasi Hasil Belajar. Yogyakarta: Pustaka Belajar.

Sanaky, Al Hujair. (2013). Media Pembelajaran Interaktif dan Inovatif. Yogyakarta: Kaukaba Dipantara.

Suprijono, Agus. (2013). Cooperative Learning Teori dan Aplikasi PAIKEM. Yogyakarta: Pustaka Belajar

Susilana, Rudi dan Cepi Riyana. (2009). Media Pembelajaran: Hakikat, Pengembangan, Pemanfaatan, dan Penilaian. Bandung: CV Wacana Prima

Tampubolon, Saur. (2014). Penelitian Tindakan Kelas Untuk Pengembangan Profesi Pendidik dan Keilmuan. Jakarta: Erlangga.

Utami, Dwi Tyas. (2010). Panduan PAKEM PKn SD. Jakarta: Erlangga

Yuni Suantini, Ni LP., I N Jampel, I W Widiana. (2013). Pengaruh Model Pembelajaran Kooperatif Tipe CIRC Terhadap Pemahaman Konsep IPA Siswa Kelas IV di Gugus II Kecamatan Gerokgak. Mimbar PGSD. Vol. 1 No. 1.

Widiana, I Wayan. (2016). E-Modul Berorientasi Pemecahan Masalah Dalam Pembelajaran Statistik Inferensial. Prosiding Semnas Hasil Penelitian. (http://jurnal.unmas.ac.id/index.php/pros/article/view/340)

Widiana, I W., I N Jampel. (2016). Learning Model and Form of Assesment toward the Inferensial Statistical Achievement By Controlling Numeric Thingking Skills. International Journal of Evaluation and Research in Education (IJERE). Vol. 5 No. 2. 